\title{
Coagulation Index Measurement
}

National Cancer Institute

\section{Source}

National Cancer Institute. Coagulation Index Measurement. NCI Thesaurus. Code

C112239.

A measurement of the efficiency of coagulation of a biological specimen. This is

calculated by a mathematical formula that takes into account the $\mathrm{R}$ value, $\mathrm{K}$ value, angle and maximum amplitude of clot formation. 